\title{
PENGARUH AKTIFITAS FISIK AEROBIK DAN ANAEROBIK TERHADAP JUMLAH LEUKOSIT PADA MAHASISWA ILMU KEOLAHRAGAAN UNIVERSITAS NEGERI MEDAN
}

\author{
Oleh \\ Novita Sari Harahap ${ }^{1}$, Urat Purnama Pahutar ${ }^{2}$ \\ ${ }^{1}$ Fakultas Ilmu Keolahragaan Universitas Negeri Medan \\ ${ }^{2}$ Fakultas Ilmu Keolahragaan Universitas Negeri Medan \\ Email: novitahrp74@gmail.com
}

\begin{abstract}
Abstrak
Aktifitas fisik secara umum dapat mempengaruhi fungsi sistem di dalam tubuh salah satunya adalah sistem hematologi seperti leukosit, eritrosit dan trombosit. Tujuan penelitian ini untuk mengetahui pengaruh aktifitas fisik aerobik dan anaerobik terhadap jumlah leukosit pada mahasiswa Ilmu Keolahragaan Universitas Negeri Medan. Penelitian ini merupakan kuasi-eksperimental dengan rancangan pre-post-test group design. Subjek penelitian sebanyak 20 orang mahasiswa Ilmu Keolahragaan Universitas Negeri Medan, dengan menggunakan tehnik purposive sampling, dibagi 2 kelompok yaitu kelompok aktifitas fisik dan kelompok aktifitas anaerobik. Jumlah/leukosit diukur/sebelum dan setelah aktifitas fisik aerobik dan aktifitas anaerobik. Analisis data menggunakan uji $t$. Hasil penelitian menunjukkan terdapat pengaruh yang bermakna sebelum dan setelah aktifitas fisik aerobik terhadap peningkatan jumlah leukosit $(6,84 \pm 1,68$ vs $11,01 \pm 2,84 ; p=0,000$ ). Terdapat pengaruh yang bermakna sebelum dan setelah aktifitas fisik anaerobik terhadap peningkatan jumlah leukosit $(7,54 \pm 1,67$ vs $11,00 \pm 1,69 ; p=0,000$ ). Tidak terdapat perbedaan yang bermakna antara aktifitas aerobik dan aktifitas fisik anaerobik terhadap peningkatan jumlah leukosit $(11,01 \pm 2,84$ vs $11,00 \pm 1,69 ; p=0,999)$. Kesimpulan bahwa aktifitas fisik aerobik dan aktifitas anaerobik ber pengaruh terhadap peningkatan jumlah leukosit, akan tetapi tidak terdapat perbedaan antara aktifitas aerobik dan aktifitas anaerobik terhadap peningkatan jumlah leukosit.
\end{abstract}

Kata kunci : Leukosit, Aerobik, Anaerobik

\section{A. PENDAHULUAN}

Aktifitas fisik merupakan modulator yang berpengaruh luas terhadap terhadap fungsi biologis. Pengaruh yang terjadi dapat positif yaitu memperbaiki maupun pengaruh negatif yaitu menghambat atau merusak fungsi biologis tersebut (Harjanto, 2005).

Berdasarkan proses biokimia pembentukan energi, aktifitas fisik dibagi menjadi dua, yaitu aktifitas fisik aerobik dan anaerobik (Willmore dan Costill 2008). Aktifitas fisik aerobik merupakan aktifitas yang bergantung terhadap ketersediaan oksigen untuk membantu proses pembentukan ATP (Adenosin Tri Phospat) yang akan digunakan 
sebagai sumber energi sedangkan aktifitas fisik anaerobik adalah aktifitas fisik yang tidak membutuhkan oksigen pada proses pembentukan sumber energinya. Aktifitas fisik anaerobik bergantung pada energi yang disimpan di otot dan hasil dari proses glikolisis (Muliadin 2009).

Aktifitas fisik merupakan salah satu faktor stres yang dapat memberikan perubahan secara fisiologi terhadap fungsi sistem hematologi seperti perubahan jumlah leukosit (Buyukyazi dan Turgay 2000; Bhatti \& Shaikh 2007; Hazar dan Yilmaz 2008). Sistem hematologi terdiri atas darah dan tempat darah dihasilkan. Darah terbagi atas selsel darah yaitu, eritrosit (sel darah merah), leukosit (sel darah putih), dan trombosit (keping darah). Leukosit adalah sel darah putih yang berfungsi sebagai pertahanan tubuh, mengandung inti. Didalam darah manusia, normal didapati jumlah leukosit ratarata 4000-11000 sel/mm3, bila jumlahnya lebih dari $11000 \mathrm{sel} / \mathrm{mm} 3$, keadaan ini disebut leukositosis, bila kurang dari $4000 \mathrm{sel} / \mathrm{mm} 3$ disebut leukopenia (Ganong, 2010; Sherwood 2014).

Penelitian yang dilakukan oleh Isprayoga (2015) menunjukkan $\sqrt{\text { bahwa ada }}$ peningkatan jumlah leukosit pada individu yang diberi latihan aerobik lari. Penelitian yang dilakukan oleh Atan \& Alacam (2015) juga menunjukkan bahwa ada peningkatan jumlah leukosit setelah aktifitas fisik aerobik dan anaerobik.

Berdasarkan uraian di atas dapat maka masih belum banyak penelitian yang menjelaskan efek latihan aerobik dan anaerobik terhadap komponen darah perifer. Jadi tujuan penelitian adalah untuk mengetahui pengaruh latihan aerobik dan anaerobik terhadap jumlah leukosit pada mahasiswa Ilmu Keolahragaan Universitas Negeri Medan.

\section{B. METODE PENELITIAN}

Penelitian ini dilakukan di di Stadion Universitas Negeri Medan (Unimed) dan Laboratorium Kesehatan Daerah Medan. Secara umum rancangan penelitian ini adalah eksperimental dengan rancangan penelitian Pretes - Postest Group Design. Subjek penelitian mahasiswa Ilmu Keolahragaan Unimed sesuai kriteria berjenis kelamin lakilaki, tidak melakukan latihan fisik sebelum melakukan penelitian dan bukan atlet.

Subjek penelitian berjumlah 20 orang, secara acak dibagi menjadi dua kelompok, yaitu kelompok A atau kelompok aktifitas fisik aerobik dan kelompok B 
atau kelompok aktifitas fisik anaerobik masing-masing 10 orang. Pengukuran jumlah leukosit pada kelompok A dan kelompok B dilakukan sebelum dan setelah aktifitas fisik aerobik dan anaerobik. Pada kelompok A, subjek penelitian melakukan lari 15 menit dan kelompok B, subjek penelitian melakukan lari sprint $300 \mathrm{~m}$. Pemeriksaan jumlah leukosit dilakukan di Laboratorium Kesehatan daerah Sumatera Utara menggunakan alat Haematology Analizer.

Data dianalisis dengan program SPSS V 23.0 for windows dengan tingkat signifikan $\mathrm{p} \leq 0,05$. Uji yang dilakukan analisis bivariat yaitu uji - $\underline{t}$, yang didahului uji Normalitas dengan Kolmogorov-Smirnov.

\section{HASHL DAN PEMBAHASAN}

1. Hasil

Berdasarkan hasil analisis data dengan uji-Normalitas (Kolmogorov-Smirnov), p>0,05, menunjukkan data berdistribusi normal seperti pada tabel 1 .

Tabel 1. Hasil uji normalitas pengaruh aktifitas aerobik dan anaerobik

\begin{tabular}{lcccc}
\multicolumn{2}{c}{ terhadap jumlah leukosit } & & \\
\hline \multirow{2}{*}{ Kelompok } & \multicolumn{2}{c}{ Pre test } & \multicolumn{2}{c}{ Post test } \\
\cline { 2 - 4 } & $\begin{array}{c}\text { Kolmogorov } \\
\text { Smirnov test }\end{array}$ & $\mathbf{P}$ & $\begin{array}{l}\text { Kolmogorov } \\
\text { Smirnov test }\end{array}$ & $\mathbf{p}$ \\
\hline Aerobik & 0,582 & 0,887 & 0,512 & 0,955 \\
Anaerobik & 0,996 & 0,274 & 0,507 & 0,959 \\
\hline Keterangan : $\mathrm{p}>0,05:$ data berdistribusi normal & & &
\end{tabular}

Berdasarkan hasil pengukuran jumlah leukosit sebelum aktifitas fisik aerobik pada 10 subjek penelitian, didapatkan rerata jumlah leukosit sebesar $6,84\left(10^{3} / 1\right)$. Jumlah leukosit tertinggi adalah $8,90\left(10^{3} / 1\right)$ dan terendah sebesar 4,4 $\left(10^{3} / 1\right)$, standar deviasi jumlah leukosit sebelum aktifitas fisik aerobik adalah sebesar 1,68. Sesaat setelah aktifitas fisik, pengukuran kembali dilakukan terhadap 10 subjek penelitian dan didapatkan hasil rerata jumlah leukosit sebesar $11,01\left(10^{3} / 1\right)$. Jumlah leukosit tertinggi adalah 14,40 (10³/1) dan terendah sebesar 6,60 (10 $3 / 1)$, standar deviasi jumlah leukosit sebelum aktifitas fisik aerobik adalah sebesar 2,84, seperti tercantum pada tabel 2. 
Tabel 2. Kadar rerata jumlah leukosit sebelum dan sesudah aktifitas aerobik dan anaerobik

\begin{tabular}{|c|c|c|c|c|c|}
\hline \multirow[t]{2}{*}{$\begin{array}{c}\text { Jumlah Leukosit } \\
\qquad\left(1^{3} / \mathrm{I}\right)\end{array}$} & \multicolumn{2}{|c|}{$\begin{array}{l}\text { Aktifitas } \\
\text { Aerobik }\end{array}$} & \multicolumn{2}{|c|}{$\begin{array}{c}\text { Aktifitas } \\
\text { Anaerobik }\end{array}$} & \multirow{2}{*}{$\begin{array}{c}\begin{array}{c}\text { Perbedaan } \\
\text { aktifitas } \\
\text { aerobik dan } \\
\text { anaerobik }\end{array} \\
\mathrm{p} \\
\end{array}$} \\
\hline & Mean \pm SD & $\mathrm{p}$ & Mean \pm SD & $\mathrm{p}$ & \\
\hline Sebelum aktifitas & $6,84 \pm 1,68$ & & $7,54 \pm 1,67$ & & \\
\hline Setelah aktifitas & $11,01 \pm 2,84$ & $0,000 *$ & $11,00 \pm 1,69$ & $0,000 *$ & 0,365 \\
\hline
\end{tabular}

Keterangan: $*=$ signifikan $(\mathrm{p} \leq 0,05), \mathrm{N}=$ jumlah sampel, Mean : rerata, $\mathrm{SD}:$ simpangan baku

Berdasarkan hasil uji statistik, ada pengaruh yang bermakna peningkatan ratarata jumlah leukosit setelah aktifitas aerobik $(\mathrm{p}=0,000)$ dan peningkatan rata-rata jumlah leukosit setelah aktifitas anaerobik $(\mathrm{p}=0,000)$ dibandingkan sebelum aktifitas aerobik dan aktifitas anaerobik. Akan tetapi, tidak Ada perbedaan yang bermakna peningkatan rata-rata jumlah leukosit $(\mathrm{p}=0,365)$ antara aktifitas aerobik dengan aktifitas anaerobik, seperti tercantum pada tabel 2 dan gambar 1 .

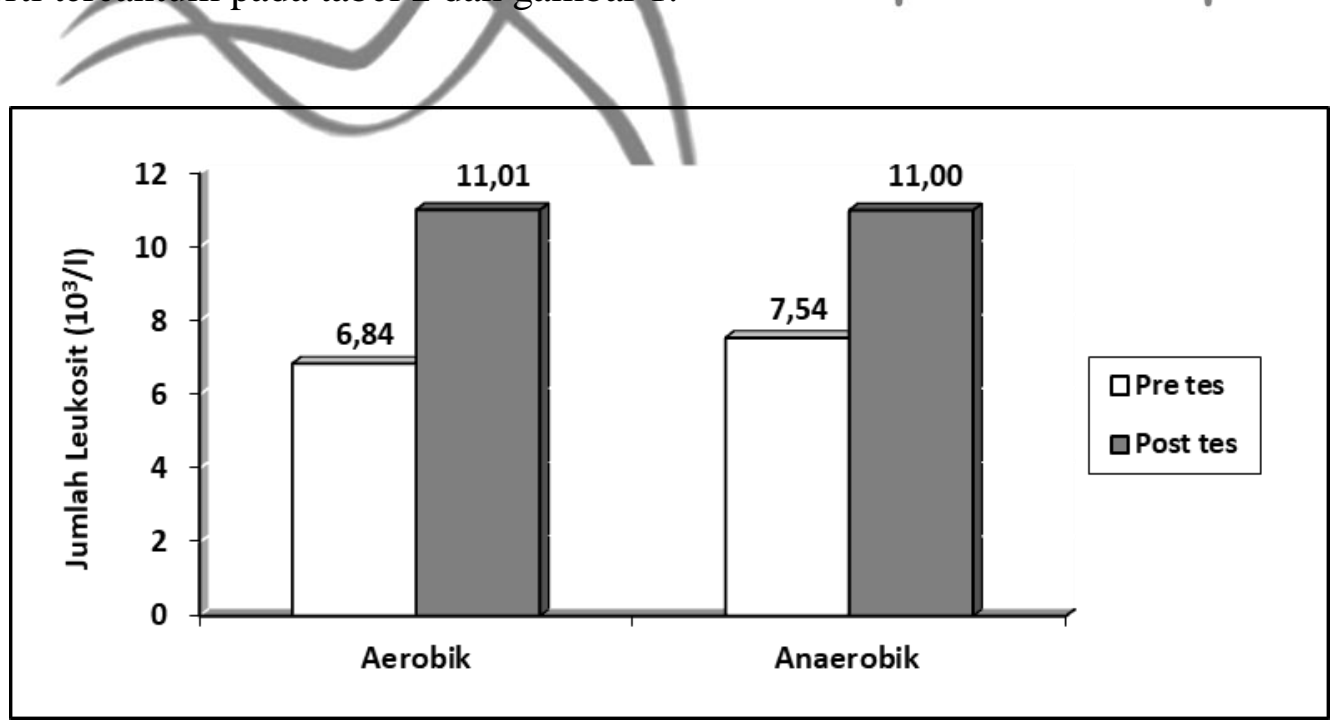

Gambar 1. Rerata jumlah leukosit pada aktifitas aerobik dan anaerobik

\section{PEMBAHASAN}

Dari hasil uji statistik menunjukkan bahwa ada pengaruh yang bermakna aktifitas aerobik dan aktifitas anaerobik terhadap peningkatan jumlah leukosit, akan tetapi tidak ada perbedaan yang bermakna antara aktifitas aerobik dan aktifitas 
anaerobik. Hasil penelitian ini sejalan dengan penelitian terdahulu yang dilakukan oleh Atan \& Alacam (2015) tentang efek aktifitas aerobik dan anaerobik terhadap komponen darah menunjukkan bahwa ada peningkatan jumlah leukosit pada aktifitas fisik aerobik dan aktifitas fisik anaerobik akan tetapi tidak terdapat perbedaan antara kedua aktifitas fisik tersebut.

Penelitian oleh Mukarromah et al. (2013) menyatakan bahwa latihan aquarobik pada wanita obesitas terlihat dari hasil yang didapat jumlah leukosit meningkat setelah latihan. Penelitian terdahulu lainnya diketahui terjadi peningkataan jumlah leukosit yang signifikan segera setelah melakukan latihan fisik (Nielsen et al. 2004; Van Helvoort et al, 2007). Penelitian yang dilakukan oleh Harahap tahun 2008 menyatakan bahwa jumlah leukosit meningkat setelah melakukan aktifitas fisik maksimal.

Pada beberapa penelitian mengenai pemberian beban maksimal saat pelatihan fisik atau kelelahan yang berat ditemukan adanya perubahan jumlah leukosit pada darah tepi, yang diduga menjadi penyebab meningkatnya kejadian infeksi saluran nafas, karena terjadi penekanan fungsi imunitas, sehingga terjadi penurunan penampilan atlet. (Castel, 1993, Ksnig, 2000).

Aktifitas fisik bersifat fisiologis pada tubuh dan dapat menyebabkan perubahan seluler, seperti sel-sel darah. Hal ini tergantung dari berbagai faktor seperti jenis dan durasi latihan, iklim, status fisik tubuh, dan gizi. Aktifitas fisik juga dapat menginduksi respon kekebalan tubuh, yang ditunjukkan dengan meningkatnya jumlah leukosit (Bhatti \& Shaikh 2007).

Aktifitas anaerobik akan menyebabkan peningkatan asam laktat yang akan menyebabkan penurunan $\mathrm{pH}$ yang memicu pembentukan radikal bebas. Penurunan $\mathrm{pH}$ cendrung menyebabkan asidosis yang dapat mengganggu kerja enzim antioksidan sehingga menimbulkan stres oksidatif. Stres oksidatif akan menyebabkan inflamasi yang memicu pengeluaran leukosit untuk menghentikan inflamasi (Purnomo, 2011).

Menurut Cooper (2000) pada keadaan fisiologis, radikal bebas terbentuk 5\% dari konsumsi oksigen dan dapat dinetralisir oleh antioksidan yang ada di dalam tubuh. Namun jika laju pembentukan radikal bebas meningkat melebihi 5\% karena terpicu oleh aktifitas fisik yang berat dan melelahkan, maka kemampuan kapasitas sistem pertahanan antioksidan tidak dapat menetralisir radikal bebas yang berlebih ini. Ketidakseimbangan ini dapat menyebabkan stres oksidatif dan merangsang aktifitas sel leukosit. 
Pengaruh aktifitas fisik terhadap peningkatan jumlah leukosit, juga dapat disebabkan oleh beberapa faktor, seperti adanya mediasi dari katekolamin, kortisol, demarginasi, neuron transmiters dan peptida atau purine chemical transmiters. Peningkatan jumlah leukosit setelah aktifitas fisik dikarenakan banyaknya leukosit yang mengikut (masuk) ke dalam dinding pembuluh darah (endothelium) dengan cara merembes (diapedesis) ke dalam sirkulasi dari penyimpanannya (cadangan) secara tibatiba. Demarginasi dipengaruhi oleh hormon adrenalin yang menyebabkan menurunnya perlekatan leukosit pada endothelium (Sodique,2000; Malm, 2004).

Leukosit merupakan salah satu petanda adanya infeksi yang disebabkan oleh bakteri dan virus, serta dapat mempengaruhi kekebalan tubuh serta mendeteksi potensi terjadinya alergi, karena leukosit berperan dalam sistem pertahanan tubuh. Jumlah leukosit perifer dapat menjadi sumber informasi untuk/diagnostik dan prognosa serta gambaran adanya kerusakan organ dan pemulihán setelah latihan fisik yang berat (Sodique, 2000).

Leukosit mempunyai peranan dalam pertahanan seluler dan humoral organisme terhadap zat-zat asing. Leukosit dapat melakukan gerakan amuboid dan melalui proses diapedesis leukosit dapat meninggalkan kapiler dengan menerobos antara sel endotel dan menembus kedalam jaringan penyambung (Guyton and Hall, 2008).

Leukosit dan turunannya mempunyai fungsi untuk (1) menahan invasi oleh patogen (bakteri dan virus) melalui proses fagositosis; (2) menghancurkan sel-sel kanker yang muncul di dalam tubuh; dan (3) berfungsi memfagosit debris yang berasal dari sel yang mati atau cedera. Untuk melaksanakan fungsinya, leukosit terutama menggunakan strategi "cari dan serang" yaitu sel-sel tersebut pergi ke tempat invasi atau jaringan yang rusak. Alasan utama mengapa sel darah putih terdapat di dalam darah adalah agar mereka cepat diangkut dari tempat pembentukan atau penyimpanannya ke manapun mereka diperlukan (Sherwood, 2014)

Leukosit mempunyai peranan dalam pertahanan seluler dan humoral organisme terhadap zat-zat asingan. Leukosit dapat melakukan gerakan amuboid dan melalui proses diapedesis lekosit dapat meninggalkan kapiler dengan menerobos antara sel-sel endotel dan menembus kedalam jaringan penyambung. Jumlah leukosit per mikroliter darah, pada orang dewasa normal adalah 4000-11000, waktu lahir 15000-25000, dan menjelang hari ke empat turun sampai 12000, pada usia 4 tahun sesuai jumlah normal. 
Variasi kuantitatif dalam sel-sel darah putih tergantung pada usia. waktu lahir, 4 tahun dan pada usia 14 -15 tahun persentase khas dewasa tercapai (Guyton and Hall, 2008).

Jumlah leukosit dalam sirkulasi sangat mudah dan cepat berubah. Nilai absolut maupun relatif dapat berubah oleh stimulasi selama beberapa menit atau beberapa jam. Dampak yang paling jelas terlihat bila kelenjar adrenal dirangsang, baik secara farmakologis maupun sebagai respon terhadap kebutuhan fisiologis. Sebagian besar stimulasi fisiologis seperti olahraga, emosi, pemaparan terhadap suhu yang ekstrim, mengakibatkan leukositosis (Natale, 2003).

Aktifitas otot yang meningkat selama aktifitas maksimal dan melelahkan, mengakibatkan konsumsi oksigen meningkat 20 kali dibanding pada waktu istirahat, sehingga meningkatkan metabolisme energi melalui fosforilasi oksidatif. Aktifitas fisik potensial untuk menimbulkan ketidakseimbangan antara radikal bebas dengan antioksidan, yaitu saat antioksidan tidak dapat mengatasi radikal bebas yang terbentuk selama aktifitas fisik. Situasi ini dikenal sebagai/stres oksidatif. Stres oksidatif yang dihasilkan dari aktifitas fisik maksimal dapat menyebabkan kerusakan enzim, reseptor protein, membran lipid, dan DNA. Substansi oksigen reaktif merupakan andaman serius terhadap sistem pertahanan antioksidan seluler dan meningkatkan kerentanan jaringan terhadap kerusakan oksidatif (Leeuwenburgh \& Heinecke, 2001).

Stres oksidatif digambarkan sebagai suatu peningkatan produksi radikal bebas yang dapat mengakibatkan kerusakan jaringan. Banyak sumber yang potensial terhadap peningkatan produksi radikal bebas di dalam tubuh, salah satunya adalah akibat aktifitas leukosit. Aktifitas fagositosis dimulai setelah ada isyarat kemotaksis. Kerusakan jaringan akibat stres oksidatif menyebabkan leukosit berdiapedesis ke jaringan yang rusak dan memfagositosis jaringan yang rusak, terjadi peningkatan leukosit terhadap kerusakan oksidatif (Leeuwenburgh \& Heinecke, 2001).

\section{KESIMPULAN}

Berdasarkan hasil penelitian maka dapat disimpulkan bahwa aktifitas fisik aerobik dan aktifitas fisik anaerobik berpengaruh terhadap jumlah leukosit pada mahasiswa Ilmu Keolahragaan Unimed dan tidak ada perbedaan antara aktifitas fisik aerobik dan aktifitas fisik anaerobik terhadap jumlah leukosit pada mahasiswa Ilmu Keolahragaan Unimed. 


\section{DAFTAR PUSTAKA}

Atan, T., and Alacam H. 2015. The Effects of Acute Aerobic and Anaerobic Exercise on Blood Parameters. Anthropologist, vol.19(1). pp. 87-93.

Bhatti R. \& Shaikh D. M. 2007. The Effect of Exercise On Blood Parameters. Physiology Journal. 3(2) : 211-215.

Buyukyazi G, Turgay F. 2000. Acute and chronic effects of continuous and extensive interval running exercises on some hematological parameters. Turkish Journal of Sports Medicine, 35(3):103-113.

Castel, L.M., Poortmans, J.R, Newshome, E.A. 1993. Does Glutamin Have a Role in Reducing Infections in Athletes? European Journal Apply Physiology, 73, 48840.

Cooper, k. H. 2000. Antioxidant revolution, Tennessee, Thomas Nelson Publishers.

Ganong, W.F. 2010. Review of medical physiology,Ganong's. 23 rd edition. The McGraw-Hill Companies.Inc. USA.

Guyton \& Hall, 2008, Textbook of Medical Physiology, 11 th edition, Elsevier Saunders, Philadelphia, Pensylvania

Harahap, N.S. 2008. Pengaruh Aktivitas Fisik Maksimal Terhadap Jumlah Leukosit dan Hitung Jenis Leukosit Pada Mencit (mus musculus jantan) (Tesis). Universitas Sumatera Utara.

Harjanto. 2005. Petanda Biologis dan Faktor/Yang Mempengaruhi Derajat Stres Oksidatif Pada Latihan Olahraga Aerobik Sesaat. Penelitian eksperimental Laboratoris.

Hazar S, Yilmaz G 2008. Acute Effect of Submaximal Treadmill Exercise on Immune System. Bolu: 10 ${ }^{\text {th }}$ In-ternational Sports Science Congress Book, pp. 2325.

Isprayoga 1. 2015. Efektivitas Latihan Aerobik Pagi dan Malam Hari Terhadap Kadar Hemoglobin dan KadarLeukosit (Tesis). Universitas Negeri Semarang

Ksnig, D., Grathwohl, D., Weinstock, C., Northon, H., Berg, A. 2000. Upper Respiratory Tract Infection In Athletes: Influence Of Lifestyle, Type Of Sport, Training Effort And Immunostimulant Intake. Exercise Immunology Review, 6.

Leeuwenburgh, C., Heinecke, J.W. 2001. Oxidative Stress And Antioxidant In Exercise Cuurent Medical Chemistry, 8, 829-838

Malm, C., Berit, S., Rodica, L., Renstrom, P., Ingrid, E. L. \& Bjorn, E. 2004. Leukocytes, cytokine, growth factors and hormones in human skeletal muscle and blood after uphill or downhill running. J Physiol, 556, 983-1000Muliadin. 2009. Pengaruh Circuit Training Terhadap Nilai Kapasitas Vital Paru, Daya Tahan Otot dan Jumlah Eritrosit Mahasiswa (Tesis). Makassar : Universitas hasanuddin.

Mukarromah, S.B., Susanto, H., Riwanto, I., Rahayu, T. 2013. Pengaruh Latihan Aquarobik Terhadap Jumlah Hitung Lekosit Pada Wanita Obesitas Di Kota Semarang. Jurnal Media Ilmu Keolahragaan Indonesia. Vol. 3, Edisi 1.

Natale, V.M., Brenner, I.K, Moldoveanu, A.I, Vasiliou, P, Shek, P. Shephard, R.J. 2003. Effects of three different types of exercise on blood leukocyte count during and following exercise. Sao Paulo Med J, 9-14.

Nielsen, H.G, Hagberg, I.A. \& Lyberg, T. 2004. Marathon Running Leads to Partial Exhaustion of ROS - Generating Capacity in Leukocytes. Medicine \& Science in Sports \& Exercise. Vol. 36, no. 1, pp. 68-73.

Pharma, N. 2004. Antioxidant supplementation enhances neutrophil oxidative burst in trained runners following prolonged exercise. IJSNM, 13, 13-33. 
Purnomo. M 2011, Asam laktat dan aktivitas SOD eritrosit pada fase pemulihan setelah latihan submaksimal', Jurnal Media Ilmu Keolahragaan Indonesia, vol.1, no. 2.

Sherwood L. 2014. Fisiologi Manusia Dari Sel Ke Sistem. Edisi 6. Penerbit Buku Kedokteran EGC. Jakarta.

Sodique, N.O., Enyikwola, Ekani,A.U. 2000. Exercise Induced Leucocytosis In Some Healthy Adult Normal. Afr.J. Biomed.Res., 3, 85-88.

Willmore, J.H and Costill, D.L. 2008, Physiology of sport and exercise, USA, Human Kinetics, pp 216-236.

Van Helvoort, H.A., Heijdra, Y. F., De Boer R.C. \& Swinkels, A. 2007. Six-Minute Walking Induced Systemic Inflammation and Oxidative Stress in Muscle-Wasted COPD Patients. in Thijs, M. H. \& Dekhuijzen, P. N. R. (Eds.) Netherlands, American College of Chest Physicians. Vol. 131, no. 2, pp.439-45

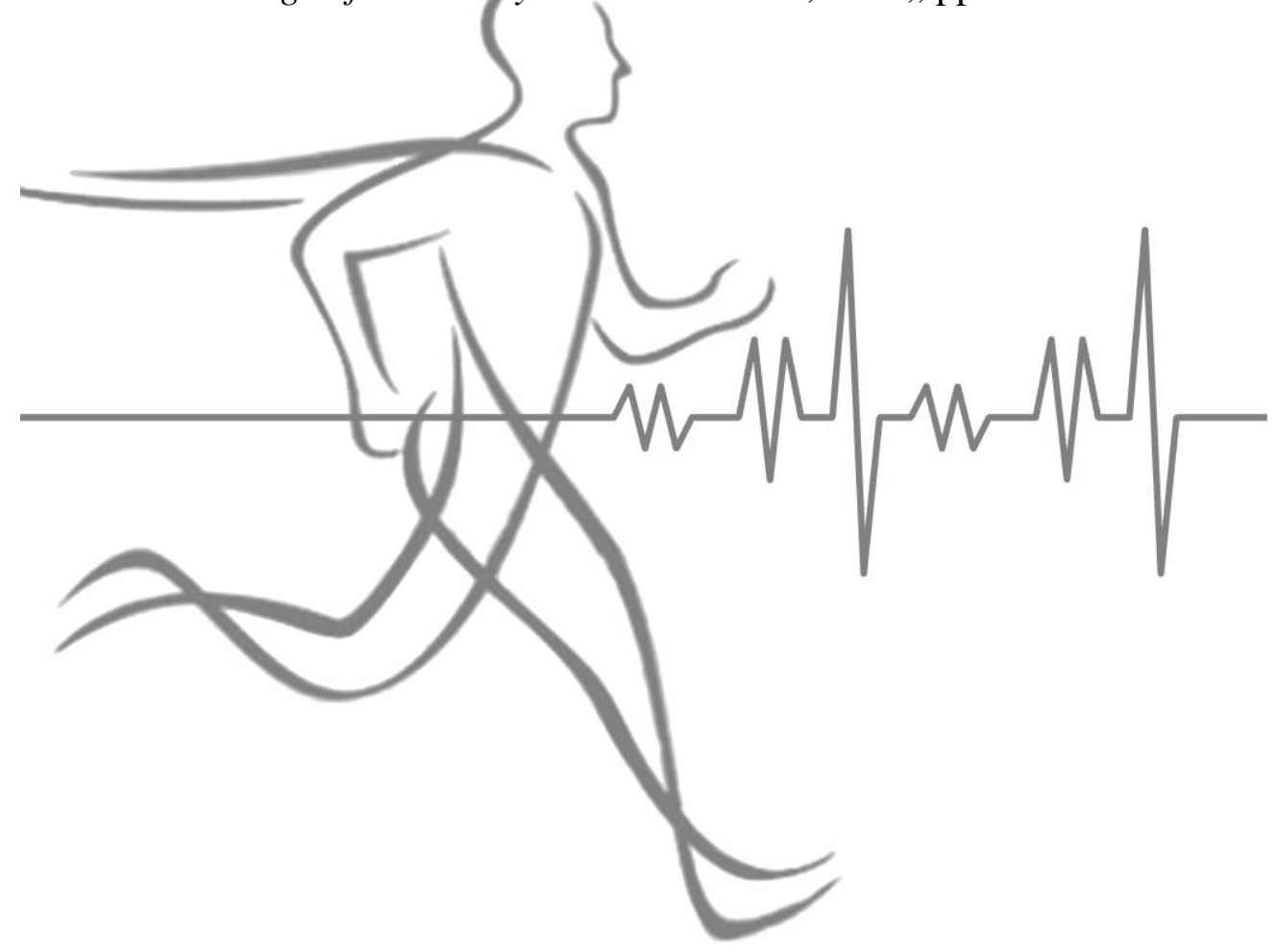

